\title{
Plotting the coloniality of conservation
}

\author{
Yolanda Ariadne Collins a1 \\ Victoria A. Maguire-Rajpaul ${ }^{\mathrm{b}}$ \\ Judith E. Krauss ${ }^{c}$ \\ Adeniyi P. Asiyanbi ${ }^{\mathrm{d}}$ \\ Andrea Jiménez ${ }^{\mathrm{c}}$ \\ Mathew Bukhi Mabele ${ }^{f}$ \\ Mya Alexander-Owen ${ }^{a}$ \\ ${ }^{a}$ University of St. Andrews, Scotland, UK \\ ${ }^{\mathrm{b}}$ University of Oxford, UK \\ ${ }^{c}$ University of Sheffield, UK \\ ${ }^{\mathrm{d}}$ University of British Columbia, Canada \\ ${ }^{\mathrm{f}}$ University of Dodoma, Tanzania \\ awaiting final page numbers Dec. 2021
}

\begin{abstract}
Contemporary and market-based conservation policies, constructed as rational, neutral and apolitical, are being pursued around the world in the aim of staving off multiple, unfolding and overlapping environmental crises. However, the substantial body of research that examines the dominance of neoliberal environmental policies has paid relatively little attention to how colonial legacies interact with these contemporary and market-based conservation policies enacted in the Global South. It is only recently that critical scholars have begun to demonstrate how colonial legacies interact with market-based conservation policies in ways that increase their risk of failure, deepen on-the-ground inequalities and cement global injustices. In this article, we take further this emerging body of work by showing how contemporary, market-based conservation initiatives extend the temporalities and geographies of colonialism, undergird long-standing hegemonies and perpetuate exploitative power relations in the governing of nature-society relations, particularly in the Global South. Reflecting on ethnographic insights from six different field sites across countries of the Global South, we argue that decolonization is an important and necessary step in confronting some of the major weaknesses of contemporary conservation and the wider socio-ecological crisis itself. We conclude by briefly outlining what decolonizing conservation might entail.
\end{abstract}

Key Words: Coloniality; decolonizing conservation; market-based conservation; nature-society relations; Global South; pluriverse; conviviality; indigenous knowledges

\footnotetext{
${ }^{1}$ Dr. Yolanda Ariadne Collins, Lecturer, University of St. Andrews, Scotland, UK. Email: yac1 "at" st-andrews.ac.uk. Victoria A. Maguire-Rajpaul, DPhil Candidate, University of Oxford, UK. Dr. Judith E. Krauss, Post-Doctoral Researcher, University of Sheffield, UK. Dr. Adeniyi P. Asiyanbi, Assistant Professor, University of British Columbia, Canada. Dr. Andrea Jiménez, Lecturer, University of Sheffield, UK. Dr. Mathew Bukhi Mabele, Lecturer, University of Dodoma, Tanzania. Dr. Mya Alexander-Owen, Associate Lecturer, University of St. Andrews, Scotland, UK. We are thankful to Dan Brockington, Esteve Corbera Elizalde and Sara Maestre-Andrés for organizing this special issue, and Simon Batterbury and $J P E$ for editorial support. We are also grateful to Dorothea Kleine and two anonymous reviewers for their careful and helpful feedback on this work. We would like to thank everyone in our different research sites who have made this work possible. In addition, Judith Krauss would like to thank the NORFACE/Belmont Forum-funded project 'Convivial conservation' (ESRC ES/S007792/1). All errors remain our own. This is the xx article in Dan Brockington, Esteve Corbera and Sara Maestre (eds.). 2021. "The challenges of decolonizing conservation", Special Section of the Journal of Political Ecology 28.
} 


\section{Résumé}

Des politiques de conservation contemporaines et basées sur le marché, conçues en tant que rationnelles, neutres et apolitiques, sont mises en œuvre dans le monde entier dans le but d'éviter les nombreuses crises environnementales qui se développent et se juxtaposent à présent. Néanmoins, les nombreuses études de recherche qui examinent la prééminence des politiques environnementales néolibérales ont accordé relativement peu d'attention à la manière dont les héritages coloniaux interagissent avec ces politiques de conservation contemporaines et basées sur le marché, mises en œuvre dans les pays du Sud. Ce n'est que récemment que les chercheurs ont commencé à démontrer comment les héritages coloniaux interagissent avec les politiques de conservation basées sur le marché de façon à augmenter leur risque d'échec, à approfondir les inégalités sur le terrain et à renforcer les injustices mondiales. Cet article vise à approfondir cet ensemble de travaux émergents en montrant comment les initiatives contemporaines de conservation -basées sur le marché prolongent les temporalités et les géographies du colonialisme-soutiennent les hégémonies anciennes, et perpétuent les relations de pouvoir d'exploitation dans la gestion des relations nature-société, en particulier dans les pays considérés globalement du Sud. En réfléchissant sur des observations ethnographiques réalisées sur six sites différents dans des pays du Sud nous soutenons que la décolonisation est une étape primordiale et nécessaire pour faire face à certaines des principales déficiences majeures de la conservation contemporaine, de même que à la crise socio-écologique actuelle/globale. Nous concluons en décrivant brièvement les grandes lignes de ce que pourrait impliquer la décolonisation de la conservation.

Mots Clés: Colonialité; décolonisation de la conservation; conservation basée sur le marché; relations naturesociété; Sud global; pluriversité; convivialité; savoirs autochtones

\section{Resumen}

Las políticas de conservación contemporáneas y basadas en el mercado y que se presentan como racionales, neutrales y apolíticas, se están aplicando en todo el mundo con el objetivo de evitar múltiples crisis ambientales. Sin embargo, la mayor parte de la investigación que examina el predominio de las políticas ambientales neoliberales ha prestado relativamente poca atención a cómo los legados coloniales interactúan con estas políticas de conservación contemporáneas y basadas en el mercado promulgadas en el Sur Global. Solo recientemente se ha comenzado a demostrar cómo los legados coloniales interactúan con dichas políticas y se ha demostrado como aumentan su riesgo de fracaso, profundizan las desigualdades en el terreno y cimientan las injusticias globales. En este artículo, expandimos este cuerpo de trabajo emergente al mostrar cómo las iniciativas de conservación contemporáneas, basadas en el mercado, extienden las temporalidades y geografías del colonialismo, reforzando las hegemonías y perpetuando relaciones de poder y explotación en la gobernanza de las relaciones naturaleza-sociedad, particularmente en el Sur Global. Reflexionando sobre la experiencia etnográfica de seis estudios de campo en diferentes países del Sur Global, argumentamos que la descolonización es un paso importante y necesario para enfrentar algunas de las principales debilidades de la conservación contemporánea y, más ampliamente, de la crisis socioecológica Concluimos con una breve descripción de lo que podría implicar la conservación con un enfoque decolonizador.

Palabras Claves: Colonialidad; descolonización de la conservación; conservación basada en el mercado; relaciones naturaleza-sociedad; Sur global; pluriverso; convivencialidad; conocimientos indígenas

\section{Introduction}

Contemporary and market-based conservation policies, often constructed as rational, neutral and apolitical, are being pursued around the world with the aim of staving off multiple, unfolding and overlapping environmental crises. However, the substantial body of research that examines the dominance of neoliberal environmental policies has paid relatively little attention to how colonial legacies interact with these policies. Rather, there is a tendency in neoliberal conservation to privilege novelties and discontinuities, with much analysis framed around the question of 'what is new?' in relation to neoliberal environmental governance and the green economy (Boyd et al., 2011: 601; Fairhead et al., 2012: 239; Corson and McDonald, 2012: 264).

Studies are beginning to draw more attention to this gap. For instance, Kashwan et al. (2021) recently traced the persistence of colonial legacy and racialized power relations across recent conservation approaches including the market-based approach, explicitly calling for decolonized, inclusive and regenerative approaches to conservation. Taking further earlier indications of racial and neocolonial undercurrents in carbon offsetting 
(Lohmann, 2008; Bachram, 2004), Collins (2019) analyzed how Guyana and Suriname's preparations for the Reducing Emissions from Deforestation and forest Degradation initiative (REDD+) was shaped by colonial histories sedimented in "racialized subjectivities and [related] land management practices" (Collins, 2019: 38). Indeed, some critical scholars do recognize how neoliberal conservation partly reflects a continuation of colonial and post-colonial enclosure of the commons and the racialized appropriation of nature and control of populations (see Fairhead et al., 2012; Leach and Scoones, 2015; Igoe and Brockington, 2007; Collard et al., 2015). Yet, we note that the persistence of colonial legacies in contemporary market-based conservation and the formidable challenge that racialized forms of oppression pose to visions and practices of more just and more sustainable conservation, demand that political ecology pay more attention to the urgency of tackling these colonial histories. This is because of its position as the field that situates much of the literature on neoliberal conservation, and that dedicates itself to interrogating the often-conflictive relationship between hegemonic economic and social structures and the natural environment (Bryant, 2015; Perreault et al., 2015).

Colonialism, as a set of practices, hinges on the forced control of space and the domination of land, bodies and nature by a foreign 'other.' The colonizing foreign 'other' either extracts those resources from the dominated country and relocates them to the colonial metropole for its benefit; or internally appropriates and accumulates land and resources in the dominated country (Tuck and Yang, 2012). In this article, we use colonialism to refer to the period beginning in the $15^{\text {th }}$ century during which Western Europeans began to set up colonies around the globe, dominating people and extracting their land and resources for their own benefit. While work within political ecology has recognized and reflected upon how colonial legacies underpin powerladen human-environment relations more broadly, it has also paid scant attention to how these dynamics can be decolonized.

In attending to this gap, we argue that contemporary and market-based conservation policies carried out in the Global South often build on and revitalize preceding colonial modes of governing nature-society relations. We support this argument by drawing on decolonial theory to re-examine our separate analyses of market-based and contemporary conservation initiatives in our varied field sites by plotting and illuminating the presence of colonial histories and supporting Eurocentric knowledge systems. Through vignettes - used here as brief windows into our research experiences in varied field sites across the Global South - we highlight the multiple shared and context dependent ways through which colonial histories refract, affect, and shape conservation policies, practices, and outcomes.

Following Büscher and Fletcher's (2020) proposal for 'convivial conservation', through which conservation landscapes are reimagined in ways that recognize that nature and society are dialectically integrated and should be managed as such, we advocate for conservation pursued as an outcome of social interaction and organization rather than as a neutral, neatly packaged and rational intervention into societies marked as problematic. In other words, decolonizing conservation requires that contemporary and neoliberal conservation's guise of apoliticism and neutrality be opened up to greater critical engagement with the societal dynamics and contexts in which it operates. Otherwise, conservation will risk deepening on-the-ground inequalities and injustices (Collins, 2019; Domínguez and Luoma, 2020) and failure (Büscher et al. 2012; Fletcher 2018). This notion of 'convivial conservation' can be actualized through a decolonial lens by adapting it to local contexts through the logic of pluriversality (Mabele et al., accepted; Krauss, 2021, this collection) which places value on a multiplicity of knowledges wherein there is no privileging of one 'truth' as universal and where links to indigenous ${ }^{2}$ knowledges are contextually re-established across the planet (Mignolo, 2018). We therefore argue in this work, for a delinking from the privileging of Eurocentric knowledge in order to make space for alternative ways of thinking about and doing historically informed, decolonial conservation.

We make this argument by first, engaging with the broader field of political ecology in order to mark out the potential of decolonial thought to contribute to its aims. Second, but relatedly, we describe the colonial matrix of power that provides the map through which we plot the coloniality of conservation. Third, we outline our methods in careful view of our positionality and then introduce the vignettes. We turn next towards

\footnotetext{
2 In this paper, we use the word 'indigenous' as an adjective or grouping, rather than a name. When we refer to the names indigenous communities have chosen themselves, we capitalize them.
} 
discussing the patterns we identify and, finally, conclude with a reflection on the potential of decolonial theory to make space for multiple ways of relating with nature.

\section{Towards a decolonial political ecology}

Political ecology has made several contributions to postcolonial theories of the environment - a body of scholarship that addresses the ways in which colonialism informs the present. For instance, political ecologists have demonstrated that racist, colonial representations that dehumanized indigenes in colonial Africa were wielded alongside violent coercion and colonial laws to simultaneously present them as part of the landscape to be conserved and as threats to the 'landscape's conservation (Neumann, 1998; Fairhead and Leach, 1998). Importantly, they highlighted how the reconstitution of the colonies as frontiers for the expansion of the circuits of capitalism, a process which was interwoven with the priorities, strategies and practice of colonial environmental conservation, foreshadowed and preceded contemporary conservation (Beinart and Hughes, 2007). Political ecologists have also attended to the multiple logics, interests, and tactics that converged around indigenous engagement with colonial environmental rule (see for example Escobar, 1995; Rocheleau, 2015).

While political ecology has been productive in recognizing and reflecting on the impact of colonialism on power-laden human-environment relations, it has scarcely demonstrated commitment to actively decolonizing environmental relations and conservation. There are significant differences between 'post-' and 'de-' colonial knowledge traditions, amongst which are their intellectual influences, traditions, geographical origins, and propositions. Furthermore, decolonial schools of thought draw on longer colonial histories than do postcolonial ones. Explicitly decolonial epistemological and praxis has had at best a mixed success across the field, with work framed as such sometimes receiving little attention - critical or not (see for instance, Kim et al. 2012a, 2012b). The current global intersection of environmental, economic and social crises, however, calls for political ecology to explicitly develop an agenda that is sensitive to the ways in which conservation interacts with and exacerbates societal injustices rooted in exploitative colonial histories. Decolonization, in this vein, requires the active and intentional deconstruction and delinking from these colonial structures and knowledge systems (Tlostanova, 2019).

In line with recent critiques that "political ecology still primarily adheres to research practices and paradigms that have been developed in the West, regardless of its diversity and dynamism as a field of research", we agree that political ecology has some way to go in its commitment to non-Western ontologies and paradigms (Schulz, 2017: 125). Hence, there are multiple opportunities to consolidate political ecology's strength through decolonial work. On the one hand, one could talk of a re-reading of existing political ecology works through the lens of decolonial thinking, breaking apart, or at least highlighting, the overreaches of its underpinning knowledge systems and power structures often rooted in the West. On the other hand, future political ecology research work and activism are well timed to make meaningful contributions to advancing the frontiers of decolonized conservation, once the nexus of environmental change and racialized marginalization is better appreciated through a focus on the multiple ways in which colonial histories undergird contemporary and neoliberal conservation. Anibal Quijano's (2000) Colonial matrix of power embodies a crucial starting point for thinking about decolonizing conservation and shall be parsed more extensively in order to prepare for taking a decolonial lens to the vignettes.

\section{The colonial matrix of power}

Quijano's thesis (2000) views the persistent impact of colonialism on contemporary society as a matrix of intersecting power structures that perpetuates colonial patterns of producing benefits for certain actors in the West while disenfranchising other actors. The major intersecting axes of this model are the axis of Capitalist Modernity and the Coloniality of Power. Indeed, it is impossible to address coloniality without taking into consideration modernity, as within this approach to decoloniality, the former has been regularly characterized as the darker side of the latter- they are two sides of the same coin (Mignolo, 2011; Maldonado-Torres, 2007). Each vignette explored within this article features these intersecting axes and so, it is important to have a working understanding of each in order to fully appreciate the specifics of each case and by extension the authors' call for decolonizing approaches to conservation. 
Modernity in this context refers to a specific Eurocentric narrative in which the achievements of Western civilizations are celebrated as though they came into being within a European bubble, separate and apart from the colonial project, its knowledge exchanges and its financial benefits to Europe (Mignolo, 2011). Grosfoguel (1996) reminds us that this notion of modernity finds its beginnings in the $18^{\text {th }}$ century's Age of Enlightenment, during which secularism came to the fore. European society during this time experienced a reformation in which the virtues of science came to be privileged and everything that accompanied it followed suit. One of the most important ideas associated with modernity is the notion of rationality, wherein the Western individual was considered to be politically free, and to have control over their own destiny - an approach which was abstracted upwards to the state. Accordingly, the state was free to engage in rational, objective, supposedly neutral, science-informed choices to control its progressive development (Grosfoguel, 2008a).

The term Capitalist Modernity highlights in particular the relationship between the commercial aspects of the colonial project in the 'New World' and European modernity. The triangular trade and its concomitant financial benefits played a significant role in industrialization. Industrialization, in turn, further changed the relationship humans had with the environment, so that 'nature mutated into natural resources' (Mignolo, 2011) and the exploitative, commoditized relationship emerged. As globalized trade in natural resources prospered, liberalism, which was underwritten by Enlightenment ideas, then emerged as an embodiment of this intensified relationship - one author even refers to it as 'the pinnacle of the Enlightenment' (Letizia, 2013). Viewed through this lens, the comparatively recent emergence of neoliberal conservation, which marries profit-driven and incentive-driven market logics with the goal of environmental conservation (Fletcher, 2013) is deeply entangled with the axis of Capitalist Modernity within the Colonial Matrix of Power.

As this conceptualization of Modernity is clearly linked to the resource extractive colonization of the Americas, it follows that the complementary axis in this model is the Coloniality of Power. This axis essentially outlines the various entangled, hierarchical systems that underscored colonial logics, having emerged through the colonization of the Americas (Maldonado-Torres, 2007; Quijano and Wallerstein, 1992). The 'Coloniality of Being' shows how racially defined hierarchies established during colonialism continue to shape and inform global distributions of power. These racialized imaginaries are well established within postcolonial critiques and are linked to the colonial power-knowledge nexus. Not only did the colonial master have the power to create knowledge about the 'Other' that deemed them inferior, but that knowledge also served to demote indigenous knowledge systems and, thereby, preserve the primacy of Eurocentric thought. If indigenous people and by extension their knowledge systems were inferior, then so too were their cultural products resulting in the colonial distributions of power with which we are familiar today (Grosfoguel 2008b, 2011). The systems of racial codification, knowledge production and culture emerge repeatedly across the vignettes that follow.

Nevertheless, coloniality, the distribution of power emergent from these colonial dynamics, is foundational to the distribution of world power. Quijano's thesis is that structures cemented through the colonial enterprise bolster the distribution of power today and continue to be reflected in the ongoing global condition in which Western European countries, as former colonial centers, benefit disproportionately from activities that support capital accumulation in the former centers (Quijano, 2000; Maldonado-Torres, 2007). These power dynamics manifest variably according to context. For example, they are evident in how certain groups of mainly white Western people remain locked into the role as beneficent of capital accumulation, while other large groups of (mainly formerly colonized) people are designated as dispensable producers of goods and services to be consumed by the Global North. This dynamic reproduces the colonial international division of labor in the post-colonial era (Boatc $\breve{\alpha}, 2018$ ).

Notably, neoliberal conservation relies on some aspects of conservation that were historically wellestablished under colonial environmental rule, such as the instrumentalization of science (Evans, 2021) in the service of capital (Bryant, 1997; Fairhead and Leach, 2000), the commodification and commercialization of nature (Beinart and Hughes, 2007; Gadgil and Guha, 1992), the standardization and simplification of complex ecosystems (Scott, 1998) and the racialized appropriation of land, resources and labor (Li, 2007; Bryant, 1994). It is a concept that is therefore characterized by the intersections of Capitalist Modernity and the Coloniality 
of Power. Our article advocates for the dismantling of the structures underwriting the axes of the colonial matrix as they appear within contemporary and neoliberal conservation. It advances the integration of decolonial insights into political ecology, based on the understanding of decoloniality as an option (Mignolo, 2011; Tlostanova, 2019): a choice that requires collective reflection on individual political, ethical, and epistemic positionalities. We seek not only to identify the extent to which practices of environmental conservation are informed by colonial pasts and colonial legacy presents, but also to open spaces for varied, non-Eurocentric epistemological perspectives to emerge and thrive by disrupting the geopolitics of knowledge production.

Hence, this article brings insights from decolonial schools of thought into dialogue with the diversity of approaches in political ecology scholarship. In taking forward such a dialogue between decolonial perspectives and political ecology, we recognize the continued structuring tendencies of colonialism on the distribution of power and the shaping of identities in formerly colonized and colonizer countries around the world - tendencies that permeate conservation practice through and through. Hence, we reflect in this article on our respective fieldwork experiences that were conducted in support of political ecology research on conservation in formerly colonized places around the world. In our reflections, we pay particular attention to the ways in which conservation initiatives in myriad forms dialogue with manifestations of coloniality evident in these societies. We show in the ethnographic sketches that follow, the multiple means through which coloniality is imprinted on the implementation of market-based and contemporary conservation initiatives.

\section{Methods}

This article was developed by a group of scholars working at the nexus of development, decoloniality, environmental policy, and climate change who critically reflected on the colonial legacies perceptible in their areas of work, and in contemporary and market-based conservation more widely. Our methods are captured in Figure 1 below.

Our assembly of diverse authors echoes our recognition of the diversity within decolonizing movements and scholarship. We hereby acknowledge the invaluable contributions of those who facilitated our fieldwork, granted us access to rural communities, enlightened us with a plurality of values, and broadened our horizons to alternative epistemologies. Our findings are informed by our origins in Latin America and the Caribbean, Africa, and Europe as well as by the pursuit of our education and professions in and across these regions. The positions of privilege we have held or still hold at elite academic institutions in the Global North influenced how we frame questions, interpret data, and disseminate findings (Sultana, 2007; Trisos et al., 2021). Six of our co-authors are from colonized nations and one from a colonizer country, but our focus in this piece is on our shared role as academics illuminating the relationship between colonialism and neoliberal conservation methods in ways that are affected, but not determined, by our respective positionalities. We deem decolonized conservation as that which meaningfully engages with the realities and contexts of societies in which it operates. Thus, our vignettes share contextual details on the impacts and power asymmetries that neoliberal and contemporary conservation interventions bear upon local livelihoods.

In the following section, we delve into describing the instances where colonial histories were still evident in our field sites and imagine ways to decolonize the power asymmetries and injustices. It is important to note that the ethnographic vignettes presented here are by no means exhaustive representations of colonial histories at work in the parts of the world categorized as developing. They serve, instead, as insights into the diverse forms these colonial legacies take and their varied interactions with the market-based policies that interact with them. 


\begin{tabular}{|c|c|}
\hline Conservation intervention & Methods \\
\hline Socio-ecological ordering in Nigeria & $\begin{array}{l}58 \text { In-depth interviews with forest communities, NGO actors, } \\
\text { government officials and REDD+ consultants. Participant observation } \\
\text { in } 8 \text { specific events. } \\
\text { Archival research at } 3 \text { regional archives (Calabar, Enugu \& Ibadan) in } \\
\text { Nigeria and the British Library, UK }\end{array}$ \\
\hline $\begin{array}{l}\text { Portraying local forest use practices } \\
\text { as destructive in Tanzania }\end{array}$ & $\begin{array}{l}15 \text { focus group discussions with charcoal producers, farmers, and } \\
\text { members of village-level forest committees } \\
69 \text { in-depth interviews with purposely selected villagers and village } \\
\text { leaders; and } \\
10 \text { events of participation observation }\end{array}$ \\
\hline $\begin{array}{l}\text { Exploitative supply chains in Côte } \\
\text { d'Ivoire and Ghana }\end{array}$ & $\begin{array}{l}12 \text { smallholder focus groups, } 108 \text { farming household surveys, } 112 \\
\text { smallholder semi-structured interviews, key informant interviews, and } \\
\text { discourse analysis of various key stakeholders' perceptions of climate- } \\
\text { smart cocoa }\end{array}$ \\
\hline $\begin{array}{l}\text { A cocoa-climate partnership as a } \\
\text { microcosm of colonialities of power } \\
\text { and knowledge in German- } \\
\text { Colombian municipal 'climate } \\
\text { partnership' }\end{array}$ & $\begin{array}{l}12 \text { instances of participant observation, } 96 \text { semi-structured interviews, } \\
\text { further triangulated by document analysis and focus group } \\
\text { discussions }\end{array}$ \\
\hline $\begin{array}{l}\text { Decolonizing the myth of the noble } \\
\text { savage in Peru }\end{array}$ & $\begin{array}{l}\text { Qualitative research involving } 30 \text { semi-structured interviews with } \\
\text { experts from academia and government representatives and walking } \\
\text { sessions with indigenous leaders from the Potato Park (following } \\
\text { indigenous methodologies they adopt). }\end{array}$ \\
\hline
\end{tabular}

Figure 1: Individual research methods.

\section{Vignettes}

\section{Socio-ecological reordering of forests in Nigeria}

The colonial regulation of forests in Nigeria presents a strong case for examining how historic power dynamics have created legacies which persist in the present and are reproduced through neoliberal conservation practices. In this formerly colonized country, a longstanding intersection between capitalism and the geopolitics of knowledge production in relation to reordering the forested regions, has made the way for present day neoliberal initiatives to be introduced as supposedly sound, rational choices for conservation. A closer look 
however reveals the specific initiative of REDD+ to be a specter of colonial power dynamics which reproduces the exploitative asymmetries of the past.

The introduction of colonial state regulation of forests into (current day) southern Nigeria from the late 1890s onwards was so arbitrary that none other than the Colonial Office in London itself wondered:

...how far the Government had power with or without the consent of the Chiefs, to regulate and restrict industry upon land which was private property, and to appropriate to the Administration a share of the measure of profits derived from there. (Egboh, 1985: 43 citing Colonial Office Dispatch 1902)

But 'scientific' forestry quickly sought to rationalize such a profound socio-ecological reordering, which immediately points to the privileged position of Eurocentric knowledge in colonial contexts is relevant to this case. Colonial foresters in Nigeria pointed to widespread deforestation and consequent changes in climatic conditions. This was in addition to rampant vilification of local African uses of forests as wasteful, inefficient and unproductive, in response to which scientific forestry was supposed to guarantee the provision of all forest products in perpetuity (Forest Policy for Nigeria 1945). This combination simultaneously advanced the Eurocentric agenda, whilst delegitimizing indigenous ways of living with the land and forests. As such, over a few decades, scores of forest reserves were constituted, forest laws accumulated along with rangers to enforce them, and fees and royalties were variously imposed in part to limit the access of smaller African timber ventures, compared to their larger European counterparts (Egboh, 1985). It was the elaborate program of timber commercialization and export which left one of the most enduring legacies in southern Nigeria (Adeyoju, 1974; Von Hellermann, 2013).

As the commercialization of southern Nigeria's timber for export peaked in around the 1930s and 1940s, so did the rate of exploitation of the forest. However, while the extremely productive western forests of southern Nigeria were being denuded through commercial timber concessions that fed the British and western European markets, forests of the eastern half of the region were largely considered commercially unproductive by foresters who saw this forest as having 'very poor quality', with too little volume of prime timber species located in a difficult hilly terrain (Collier 1949: 40). By the late 1940s, D.R Rosevear, the Chief Conservator of Forests would begin to make entreaties to timber merchants to consider investing in the largely abandoned eastern forests, since concessioning was complete in the western areas and 'there was really nothing of any size available' (Brandler, 1993: 141). As such, writing in 1974, Adeyoju (1974: 100) observed that while 'much of the forest has been worked out or overexploited in the last 70 years', forests of the south-eastern areas remain 'relatively untouched.' In short, the uneven exploitation and production of southern Nigeria's forests under colonial forestry had largely produced the isolated patch of rainforest in Cross River area (formerly SouthEastern State), an area now widely regarded as 'Nigeria's last rainforest.'

In 2008 when proponents began to canvas for REDD+, protecting 'Nigeria's last rainforest' in Cross River was the fundamental ecological rationale. REDD+ seeks to motivate forest conservation by offering financial incentives to tropical forest countries to reduce deforestation as part of international climate change mitigation efforts for which Global North countries share a greater responsibility. REDD+ is premised on notions of rationality - calculations, statistics, science - and assumes that rational actors can be influenced to behave 'appropriately' through financial motivations (Collins, 2019). Evident here is a connection between the neoliberal thought underpinning this approach to conservation and Capitalist Modernity. Furthermore, the same racialized knowledge politics that allowed for 'scientific' forestry to facilitate deforestation in the first place, is underwriting the rationality of the conservation initiative, highlighting the continuity of the intersections between Capitalist Modernity and the hierarchical systems of knowledge embedded in the Coloniality of Power. In preparation for REDD+, Cross River State imposed a total ban on forest exploitation across the entire state, deployed a militarized anti-deforestation surveillance squad and resorted to elements of the forestry laws retained from colonial times to rapidly criminalize much of the local forest economy (see Asiyanbi, 2016). 
Notably, REDD+ in the Nigerian context, insofar as it is mobilized to supposedly 'save Nigeria's last rainforest', is reliant on the literal residue of the uneven application of colonial forestry. Furthermore, REDD+ itself, is a tool implicitly underwritten by colonial perspectives and which encourages the reproduction of historical colonial violence in contemporary society. The types of exclusion and violence enabled by REDD+ are made possible precisely due to the forms of regulation introduced and pursued under colonial forestry and so the multiplicity of colonial legacies involved in this case become obvious - the ecological and social conditions of possibility of contemporary conservation have been produced through colonial logics and practices many of which are even amplified today.

Decolonization in this context might thus start with broad-based, political conversations about the ways that colonial legacy has profoundly shaped rights and access to the forest, the nature of state-society relation in general (and particularly with respect to forest resources), and taken-for-granted forest management priorities, knowledge and practices. If this is a starting point, the ultimate goal would be the empowerment of communities as citizens, with equal rights and access to participate effectively in political processes that ultimately determine how conservation and forest management rules and policies are made.

\section{Portraying local forest use practices as destructive in Tanzania}

This case illuminates the centrality of the Coloniality of Power existing within the context of forest conservation in Tanzania. In particular, it illuminates the important role played by the deeper entanglements within that axis of the Colonial Matrix of Power - specifically between hierarchies of knowledge and of race. These intertwined hierarchies, intersecting with the axis of Capitalist Modernity are shown to have produced politics of exclusion in Tanzania which continue to affect lived experiences within that territory subsequent to the end of direct colonial administration. In this case, conservation activity in the form of the Sustainable Charcoal Project (SCP) shows the positive potential of the decolonial option, through pluriversal conviviality within the policy making context.

In 1891, a German colonial ordinance introduced scientific forestry in miombo woodlands, bringing with it the principle of 'sustainability' nachhaltigkeit ${ }^{3}$, where sustaining forest (timber) yields and regeneration of wood are guaranteed through forest policy (Radkau, 1996). In 1893, Eugen Krüger, the first professional forester to set foot in Tanzania, produced the earliest forest assessment report, portraying local people's forest uses (for fuelwood, livestock grazing and cultivation) as irrational and destructive, mirroring the $19^{\text {th }}$ century German understanding of peasants' forest use as raubwirtschaftlich, ruthlessly destructive and exploitative (Radkau, 1996; Sunseri, 2009). His report identified miombo ${ }^{4}$ as part of a forest succession, that if separated from people would reach a climax as closed forests, marking the beginning of state accusations of peasants' role in miombo degradation. The colonial government used the report to condemn and ban local forest uses (including charcoal making) labelling them as kulturfeindlich, hostile to civilization (Sunseri 2009). This remains to be the central legacy of German forestry involvement, as the independent Tanzanian government (through forestry policy framework) continues to label and categorize local people's forest uses as destructive to 'natural processes' in the miombo.

It is important to note that the language of these early conservation policies does not just reflect German perspectives of peasants, which might suggest that it was merely classist, but it uses the specific language of racist discourse, which permeated European colonialism. It is a discourse which portrays the 'native' as an inferior Other - an irrational savage, unable to operate within the realm of civilized thought and therefore unable to produce worthwhile knowledge (Fanon 2001; Said 1978; Bhaba 1983; Grosfoguel 2008b). In comparison, 'rational', 'scientific' European thought was privileged and superior and the irrational savage was meant to be the recipient of said knowledge, because - to use the words of Gayatri Spivak "The master is the subject of science or knowledge" (1985: 286). This discourse was designed to justify and naturalize colonial

\footnotetext{
${ }^{3}$ German words are used, as the terms and their meanings were exactly copied from German scientific forestry ideals into Tanzania's miombo woodlands.

${ }^{4}$ Miombo is a Tanzanian Nyamwezi name for the Brachystegia boehmii species. Germans later used the term to describe woodlands dominated by trees of the genera Brachystegia and Julbernardia, present in seven central and southern Africa countries: Angola, the Democratic Republic of Congo, Malawi, Mozambique, Tanzania, Zambia and Zimbabwe.
} 
conquest and to legitimize the establishment of systems of control, including administration and instruction (Hook, 2005; Quijano, 2000).

In this case, it is easy to see the intersections of the main axes in Quijano's matrix. We firstly see the influence of Capitalist Modernity on 'scientific forestry.' We can then layer this on the entanglement of two systems of hierarchy within the Coloniality of Power - systems of racial codification and of knowledge production. Eurocentric knowledge was operationalized through administration of exclusionary policies which discredited indigenous practices and denied autonomy to native Tanzanians. The continuity of this discourse in contemporary times shows how coloniality has haunted forestry policy in Tanzania. Nevertheless, in this case conservation has been introduced in a way that shows the potential benefits of the decolonial option via pluriversal conviviality - a contrast to the experience of REDD+ in the previous vignette.

Since 2012, a forestry intervention entitled 'Sustainable Charcoal Project' (SCP) has attempted to delink from the colonial understanding by formalizing charcoal making as a mechanism for reintegrating the miombo with rural livelihood desires in east central Tanzania. Funded by the Swiss Agency for Development and Cooperation and implemented by the Tanzania Forest Conservation Group, the SCP institutes the integration by 'greening' charcoal making with ecologically sound tree harvesting practices. According to one of the SCP's officials, the intervention follows the 'land sharing' principle, as the miombo are divided into forest management units, with $10 \%$ of the demarcated reserve being entirely for charcoal making. Residents in implementing villages of Ihombwe and Ulaya Mbuyuni have said that they feel a sense of having secured rights to forests, as they attain legal rights over forests found in the village land and retain $100 \%$ of all revenues accrued from charcoal making. In the two villages, more than US\$150,000 has been generated from charcoal sales, with $60 \%$ of the revenues used for local forestry activities, and $40 \%$ funding community development initiatives (see Mabele, 2020).

The SCP follows miombo ecologists' claim that the miombo woodlands are products of multiple-land use practices through history of tree cutting for charcoal making, shifting cultivation, and frequent dry-season fires that shaped the miombo for over thousands of years (e.g. Chidumayo, 2017; Lawton, 1978; Morris, 1970). Such human activities are therefore integral elements in the functioning of the miombo; making miombo as inseparable from people's welfare, livelihoods and development. In such a way, the project shifts the horizon of thinking and doing that confronts the historical legacies of German forestry ideals that were enacted on the miombo woodlands. The continued decolonization of this space for equitable partnerships would thus require co-production of priorities, assurance mechanisms and success criteria in ways that challenge the power asymmetries entrenched in funding commitments and historical inequalities. Nevertheless, SCP currently features not only convivial thinking, but also pluriversality, in the way that it has relinked to the contextually specific indigenous knowledge. This reaffirms Mignolo's (2018) assertion that multiple epistemologies do not have to be antagonistic within a single context and that the decolonial option can be productive in the conservation context.

\section{Exploitative supply chains in Côte d'Ivoire and Ghana}

This vignette illustrates the way in which supply chains in cocoa production retain important colonial residues which inform contemporary exploitative features. Conservation in this case takes the shape of industry-led initiatives which ultimately serve to further capital accumulation. It shows once more, the intersections between the two main axes of the Colonial Matrix of Power - Capitalist Modernity and the Coloniality of Power - through a more explicit engagement with the coloniality of labor in international trade. In so doing, it highlights the ways in which coloniality still affects the lived experiences of Ghanaian and Ivorian farmers and the potential for pluriversal conviviality to usher in a decisive socially just and pro-poor impact.

Cocoa (Theobroma cacao) is native to Central America rainforests where it was consumed in liquid form by local elites of the Aztec, Olmec, and Maya civilizations (Coe et al., 1996). Its introduction to the West African mainland was by European elites; specifically Swiss missionaries who in the 1870s sought to produce chocolate by shipping cocoa beans from Ghana to Switzerland to mix them with milk from cows reared on Alpine pastures (Acquaah, 1999; Cidell and Alberts, 2006). In Côte d'Ivoire, cocoa was originally cultivated 
by slaves (Banégas, 2006; Chappell, 1989). By the early twentieth century, both French and British colonial administrators had converted their Ivorian and Ghanaian subjects to cocoa cash cropping. Local people began appropriating local forests for export-oriented cocoa cultivation to satisfy European demand for cheap chocolate.

These two neighboring West African countries have dominated cocoa supplies for more than a century. Ghana became the world's largest cocoa producer in 1911 (Asuming-Brempong, 2003), and was surpassed by Côte d'Ivoire in 1978, which has remained the leading producer since then (Assiri et al., 2015; Ruf, 1995). Today, more than $60 \%$ of the world's cocoa is cultivated by smallholders in Côte d'Ivoire and Ghana (Akoto et al., 2017; Sanial and Ruf, 2018). Many enduring aspects of the global cocoa value chain, including cocoa's forest management practices, were cemented in the colonial era and continue to be reproduced invisibly in contemporary contexts. For instance, in the 1980s and 1990s the World Bank's and International Monetary Fund's Structural Adjustment Programs repeated colonial priorities by promoting export-oriented, cash (rather than native or subsistence) crops, thus marginalizing smallholder concerns and jeopardizing food security (Asuming-Brempong, 2003). Part of the developmentalism approach which finds its roots at the intersections of Enlightenment thought and racialized discourse, these neoliberal global governance mechanisms perpetuate Eurocentric policy making with colonial roots (Grosfoguel, 2008a; Johnson, 2010) and preserves the link between capitalist modernity and the coloniality of power in trade, by virtue of the geopolitics of knowledge production.

This enduring colonial legacy ensures that natural resources in the Global South continue to be exploited and exported to serve Global North consumers. Even after 140 years in mainland West Africa, cocoa's final processing, consumption, and value added reflect patterns of colonial-era political economy (Alberts and Cidell, 2016). Manuela Boatcŏ refers to this specific subset of the Coloniality of Power, as the "coloniality of labor" and argues that it functions such that "yesterday's colonies have largely tended to become today's peripheries" (2013: 309). Boatcă continues to argue that this particular coloniality allows us to more effectively grasp the 'pauperization of agricultural workers in the global periphery' (ibid. 312) as part of ongoing historical power dynamics.

Indeed, more than a century of extensive cocoa cultivation has deforested the world's top two cocoaproducing countries (Kroeger et al., 2017a), which are now predicted to lose much cocoa-suitable land by 2050 due to deforestation pressures and climate change (Läderach et al., 2013; Schroth et al., 2016). Multinational chocolate corporations have responded with 'climate-smart' cocoa (CSC) and 'zero-deforestation' cocoa schemes (Ingram et al., 2018; Krauss, 2018; Kroeger et al., 2017b). However, the corporate focus on the biophysical target of zero deforestation risks side-lining the livelihoods and concerns of already marginalized cocoa smallholders, and compounding their existing vulnerabilities (Nasser et al., 2020; Newell and Taylor, 2018). These conservation responses can therefore be seen as reproducing an historical international division of labor wherein non-European livelihoods become expendable relative to capital accumulation and Western interests.

Addressing vulnerabilities to alleviate multiple dimensions of smallholder poverty is not chocolate corporations' core concern (Odijie, 2019). Any humanitarian rhetoric found in CSC policy belies the reality of chocolate corporations acting to secure their bottom line: the continued supply of cocoa to the Global North, even if it means sabotaging Ivorian and Ghanaian rural livelihoods by not supporting smallholders to diversify into other more drought-resilient crops such as oil palm and rubber (Khatun et al., 2020; Maguire-Rajpaul et al., 2020; Ruf, 2015). Many interviewed farmers extolled the benefits of diversifying into palm especially under climate change conditions, such as "You cannot depend on cocoa only ... whereas palm you can harvest it every day, even under drought conditions." Without embedding these enmeshed diversification and poverty issues, CSC is at risk of perpetuating colonial patterns of producing benefits for Global North consumers 'at the expense of development in West African countries' (Odijie, 2018: 215).

Decolonizing the forest conservation intervention of CSC would require a reconfiguration of power away from principally an oligopoly of chocolate conglomerates from the Global North to instead including more smallholders' voices in the shaping of CSC policy and devolving management of natural resources to communities of smallholders (Maguire-Rajpaul et al., 2021). During fieldwork, smallholders recounted their 
own agro-ecological innovations that they enact to adapt to the changing climate and deforestation pressures, such as diversifying into other crops for income and improving soil fertility; producing organic fertilizers; nature-based solutions for pest and disease management, etc. Thus, smallholders' resourcefulness and expert lived experience could be embedded into a decolonized CSC agenda in such a way which reinforces constructive pluriversality (Mignolo, 2018).

\section{A cocoa-climate partnership as a microcosm of colonialities of power and knowledge}

This vignette examines a cocoa-climate relationship fostered between two municipalities in Germany and Colombia in the 2010s. This case underscores latent inequalities in the partnership which can be traced back to the Coloniality of Power and highlights multiple hierarchies within that coloniality, which facilitate this persistent inequality. These entangled hierarchies within the Coloniality of Power intersect with the axis of Capitalist Modernity in ways which reproduce negative lived experiences for the Global South. This case is powerful for revealing the ubiquitous nature of coloniality and the importance of recognizing how conservation, if not decolonized, can build new colonial relationships on the remains of historical ones.

In the 2010s, municipal climate collaborations were funded by the German government to connect different German towns and cities with municipalities in the Global South, all in the name of climate change mitigation or adaptation (Krauss, 2018). However, closer inspection of one German-Colombian 'partnership' suggests problematic qualities that belie aspirations of equitable partnerships. In this project, Colombian stakeholders' key priorities were solar electrification, repairing a small hydropower plant, technology transfer and livelihood opportunities through cocoa agroforestry which would combat deforestation. For German municipalities, the strongest emphasis was on the chocolate produced out of Colombian-grown cocoa beans, to be sold or given away in the German towns, as well as awareness-raising for climate and biodiversity matters among their own populations. The partnership ultimately skewed in favor of German interests for a number of reasons which can be traced back to the systems of hierarchy which Quijano argues are built into colonial power dynamics and underwrite the coloniality of power, namely entangled systems of racial codification, knowledge production and culture (Quijano, 2000).

For the cocoa-climate partnership, $90 \%$ of project funding stemmed from German sources, and the discrepancy of who provided funding translated into an equivalent divergence in whose priorities were to be enforced: despite German municipalities also recognizing the importance of renewable energy, the marketoriented cocoa production prevailed over renewable energy as the project's chief impetus (Krauss, 2018). The project thus prioritized chocolate, quite literally more palatable to German voters, over the Colombians' socioeconomically vital renewable energy consideration, whose climate impact may also have exceeded sequestered emissions from 90 families growing cocoa.

A public forum presenting the 'climate collaboration' to one of the German municipalities involved proved to be a microcosm of these power asymmetries. At the forum, the Colombian speakers, representing farmers, public sector and cooperatives, shared their thoughts on the project in Spanish, interpreted by the German project manager. When the German version repeatedly proved to be two to three times longer than the original, even observers non-fluent in Spanish noticed disparities. The German version was longer because the project manager added expansive explanations about the communities' remoteness and poverty. The geopolitics of knowledge production therefore privileged the Eurocentric perspective - including European perspectives about these marginalized groups themselves, which have long since become naturalized in contemporary discourses.

In this case, the German speaker chose to produce knowledge about Colombia that imposed colonial logics on that society. Firstly, the speaker's added perspective reproduced racialized inferiority discourses and secondly, assumed this perspective to be more accurate than that put forward by the Colombian speakers themselves, reinforcing the hierarchy of knowledge production. Such discourses perpetuate perceptions of the Global South as underdeveloped and to be treated as such (Escobar 1995: 212-213). What is more, Hall's emphasis on how the language used limits other ways of understanding and doing (1992) is made evident throughout this interaction. The project manager's intervention emphasizing Colombian communities' remoteness and poverty not only shapes listeners' perceptions in ways that led to a prioritization of the funders' 
over the beneficiaries' priorities. In so doing, German cultural preferences (for chocolate over substantive climate action) were also prioritized. This completes the circle that brings us back to the link between systems of hierarchy within the Coloniality of Power and Capitalist Modernity.

It is important to note that Germany does not have a direct colonial relationship with Colombia. The power relations demonstrated thusly do not stem from a direct connection between a specific colonized country and its former colonizer. Nevertheless, Germany is recognized for its leadership role in modernity as conceptualized by this approach to decoloniality, along with England and France (Mignolo 2009). It is also being increasingly recognized for its role in European colonization, where systems of racial codification and the production of knowledge were key to its colonial experience and continue to be reflected in contemporary German society and politics (Wildangel, 2020; Marmer et al., 2011; Campt et al., 1998). This highlights that coloniality does not require continuity of actors in a single context, but of institutionalized power dynamics which travel time, space and context by virtue of the universalization of Eurocentrism in the globalized world (Maldonado-Torres, 2007).

This vignette's power is in opening the question of just how Germany became imbued with the authority to intervene in Colombia's natural resource management practices rather than, for example, the other way around, and it creates much room for thinking through the global power dynamics of conservation. What was billed as a partnership to combat climate change was premised predominantly on behavioral change among Colombian smallholders growing cocoa rather than reduced German emissions. Despite the best of intentions, what could have become a participatory project allowing two very different municipalities to build a legitimate partnership among equals, was marred by entrenched knowledge and power asymmetries favoring the Global North. Even without a direct colonizing relationship, the power and knowledge dynamics at play have historical roots in racialized discourses which privilege certain provenances, knowledges and priorities over and above others. This example, by no means alone in the highly uneven conservation-development space, thus beseeches us to take seriously global historicity, local realities and priorities in any attempt to address environmental issues, rather than keeping bilateral relations locked in patronizing, somewhat dependent relationships steeped in colonizing practices. Decolonizing this space for equitable partnerships would thus require co-production of priorities and knowledge systems, assurance mechanisms and success criteria in ways that challenge the power asymmetries entrenched in funding commitments and historical inequalities (Trisos et al., 2021).

\section{Decolonizing the myth of 'the noble savage' in Peru}

This vignette shows the interplay between the main axes of Quijano's model by way of the relationship between the indigenous communities and the Peruvian administration. Within this context, the government itself is heavily imbued with a neoliberalist character which bestows upon it, colonial residues associated with Capitalist Modernity. In their interactions not only with the indigenous communities themselves, but with the researcher undertaking the field work for this case, representatives of the government invoked colonial discourses both to protect their own position and delegitimize that of the indigenous populations showing in particular how the entanglement of historical systems of racial codification and knowledge production continue to matter in this contemporary context. This case is particularly useful for underscoring the way in which the mechanisms for perpetuating colonial patterns are not always extrinsic to the post-colony.

In Peru, indigenous communities from the Potato Park initiative ${ }^{5}$ are articulated as the 'Quechuaspeaking descendants of the Incas', who not only protect the biodiversity of potatoes being lost due to climate change, but do so by following ancestral principles of complementarity, reciprocity and relationality, both between human interactions and in relation to the cycles of nature (Blaser, Costa, McGregor, \& Coleman, 2010; Hidalgo-Capitán and Cubillo-Guevara, 2019; Merino, 2018). Those living in the park produce crops following organic methods and have a collective governance model that allows them to share resources to all living in the Park. Similar traditions have existed for centuries but recent initiatives mainly led by indigenous scholars and activists have been articulated through the notion of Buen Vivir (Sumak Kawsay in Quechua language).

\footnotetext{
5 The Potato Park is a community-managed Biocultural Heritage Territory established by six Quechua communities in Pisaq, Cusco, Peru in 2000. It protects the traditional mountain agroecosystem, its indigenous biocultural heritage and institutions, and has one of the richest areas of native potato diversity in the world, all managed by the Quechua people.
} 
Whereas Buen Vivir has been adopted to support institutional government structures in Ecuador and Bolivia (with all the existing criticisms this includes), Peru's government remains neoliberal. Nonetheless, at least internationally, there is an ongoing quest for learning from indigenous people and epistemologies.

Whilst conducting research, in collaboration with a local NGO and the Potato Park, the author of this vignette organized meetings and interviews with government representatives to explore changes to existing legislation. ${ }^{6}$ The first such meeting involved a warning from the representatives about the project's approach, explaining that these communities were biased against outsiders. During an interview with a former government representative, the author was told that the research was reinforcing the 'myth of the noble savage', while, in the opinion of the government representative, indigenous people in Peru are the ones who pollute the most. These experiences complemented comments from the NGO representatives, who felt that people from the Potato Park had received little if not zero support from the government, and that they survive through what they referred to as a 'boomerang strategy', where indigenous movements seek international support to achieve pressure on government, through elaboration of international partnerships, projects, campaigns and more (Anthias 2018).

There is a two-fold weaponization of colonial discourse in this interaction that roughly coincides with established discourses of othering. This can be seen firstly in terms of the 'exoticized other' in the form of the Noble Savage (Nayar 2015) and then the 'demonized other' in the form of the ignorant/uncivilized/evil savage (Fanon, 2001; Grosfoguel, 2008b). The discourse of the exoticized other is deployed defensively as a red herring, against the researcher who is accused of perpetuating a colonial stereotype. This distracts the uncritical thinker from recognizing the Coloniality of Power underwriting the dismissal of indigenous knowledge systems and practices under the guise of rejecting a supposedly recolonizing move. This allows for an automatic disregard of indigenous people's epistemologies in overcoming existing environmental challenges. Whilst indigenous people are being praised internationally, at the national level they remain marginalized, excluded and othered.

Visible here, is the way that the intersections of racial codification and the production of knowledge result in a still-uneven relationship between Peruvian leaders and indigenous groups. This uneven relationship started with Spanish colonizers and is now being implemented by contemporary policymakers in relation to marginalized indigenous people (Quijano, 2007). This is indeed consistent with Fanon's perspective that colonizers' work is carried on in the post-colony by the native elites who have often been educated within the metropole (Fanon, 2001) - in this case elites who have adopted neoliberal world views. This vignette is an excellent illustration of Jean Paul Sartre's commentary on Fanon - that in order for the colonized to challenge the status quo, they must fight both the European master and also those members of society who act as their proxies (see preface of Fanon's Wretched of the Earth).

Indigenous-led conservation initiatives can be seen as embedded in post-colonial contexts, with government bodies reproducing colonial dynamics in the absence of the former colonizers. As such, indigenous-led conservation initiatives are marginalized from the outset, rather than accepted by Peruvian governments as legitimate spaces for conservation. As fast as the indigenous conservation efforts seek to delink from Eurocentric perspectives and relink with their traditional epistemologies and ontologies (thus moving towards pluriversal conviviality), the administration takes back control of the narrative. Conservation through the Potato Park initiative can only be decolonized by confronting and dismantling the national level rhetoric and racialized assumptions that automatically designate indigenous people as the polluting problem in the Peruvian context. Decolonized conservation, in this case, would require engagement with the broader socioeconomic context to dismantle current structures of oppression that lead to the marginalization of indigenous peoples, their knowledge and practices, thereby opening up the conservation space to additional ways of knowing and doing.

\footnotetext{
${ }^{6}$ Sources as well as specific information are anonymized to protect research participants.
} 


\section{Discussion}

The above vignettes represent snapshots of conservation initiatives in formerly colonized places. Through reflections on research conducted in our respective field sites, we identified different instantiations of colonial histories surrounding environmental use policies and practices. In the case of Nigeria, current forest laws and contemporary forest conservation practices do not only extend but also amplify specific colonial legacies in important ways, making a decolonial shift imperative and urgent. As is often the case in much of the Global South, resource claims and livelihood practices of the local people are vilified as inferior and problematic (understood as 'drivers of deforestation') and thus disposable in efforts to ostensibly address carbon emissions historically produced largely by the Global North. Indeed, in all the fieldwork sites, we encountered cases in which blame for environmental degradation was laid on locals whose subsistent and productive resource uses are often vilified in place of the global, capitalist economies to which they are responding (see, for example, Mabele, 2019; Hirons et al., 2017).

In the case of Peru, we perceived colonialism's legacy in racialized, unequal power relations that still pervade existing institutions. These relations portray indigenous peoples as subordinated, unjustly representing them as threats to the environment. Similarly, in the cases of Côte d'Ivoire and Ghana, colonialism endured through various dynamics of West African cocoa - and associated forest - governance, including the Europeans assuming roles at the top of the cocoa global value chain by governing the conduct of those who toil to produce cocoa for export to Europe. Early power asymmetries between colonizers and their West African subjects encapsulate the persistent telecoupled characteristics of cocoa governance whereby distant claims on land connect disparate geographies (Liu et al., 2013; Zimmerer et al., 2018), partly producing disciplining effects on local farmers who are often subject to the whims of external, economically more powerful actors. Similarly, profits and added value are also expropriated by external actors away from West African forests. In this vein, contemporary climate-smart cocoa initiatives that neither fairly remunerate cocoa smallholders, nor provide an adequate platform for smallholders' views reflect persistent structural conditions that call for decolonization. This is because they further concentrate power in the headquarters of multinational chocolate companies in the Global North, geographically removed from the multiple dimensions of poverty cocoa smallholders endure. Such telecoupled dynamics in which conservation initiatives are driven from abroad (Andriamihaja et al. 2019; Carrasco et al., 2017) often imply a transformation of control over natural resources (Buseth, 2017). This forms a common thread across our cases, including in the case of the German-Colombian climate collaboration; forest governance in east-central Tanzania that embrace German scientific forestry ideals, denigrating local importance of the miombo as a source of livelihood strategies; and REDD+ in Nigeria's Cross River.

In Tanzania, forest-related policy prescriptions that framed local forest uses such as charcoal making as 'disturbances' to supposedly 'natural' processes are rooted in colonial scientific understandings of humanenvironment interactions in the miombo woodland. Inherently, these prescriptions carry a language of blame towards charcoal makers, casting them as environmentally destructive populations whose activities needed to be restricted in the miombo. Hence, further delinking from such understandings requires epistemic disobedience (Mignolo, 2009) through conservation practices that reinstate the locals' choices on how they use the forest as an important dynamic in ecological maintenance of the miombo, not to mention contributing to a viable livelihood. Though not explicitly supported by state forestry authorities, the Sustainable Charcoal Project presents a decolonial possibility for dismantling the dominant coloniality of Eurocentric knowledge in conservation policies and practices within Tanzania's miombo woodlands

Across all these vignettes, several recurring and interconnected themes appear to emerge. Power asymmetries were marked between Global North and Global South. Many decades removed from the formal end of the colonial period, colonial power asymmetries continue to shape interactions between dominant and marginalized stakeholders across organizations, institutions and scales. Crucially, these relations of power intersect and privilege certain ways of understanding the world that often perpetuate entrenched colonial pretension to truth, that is, which knowledge claims are deemed truthful and by whom the truth can be declared. As outlined by Hall (1992), any particular framing not only constructs an issue in a certain way but also excludes alternative ways of framing or understanding the said issue. This privileging of Eurocentric thought and approaches was on full display across the vignettes: it was evident in how German colonial foresters claimed to know about the miombo; how colonial forestry continues to shape REDD+ interventions in Nigeria; 
how indigenous communities' knowledges were marginalized from the outset in conversations about the Potato Park in Peru; and in how the livelihoods and vulnerabilities of cocoa farmers in Colombia, Côte d'Ivoire, and Ghana were not afforded due consideration in interactions with more economically-powerful stakeholders from the Global North. The case of Colombia further reflects the coloniality of mandating behavioral change in the Global South to supposedly address global environmental problems that are inseparably linked to imperialistic mode of living and unbridled capitalist growth most pronounced in the Global North (Asiyanbi and Lund, 2020).

Central to our argument, however, is the question of how conservation initiatives carried out in the Global South came to be structured in such a top down, exclusionary manner in the first place. This is an issue that is tied directly to the colonial origins of conservation, and the continued mutual enhancement of conservation, capitalism and colonialism in all its guises (see Kashwan et al., 2021). Conservation history and more recent conservation agendas such as the 'Half Earth vision' of the leading conservation biologist E.O. Wilson, corporate zero deforestation supply chain pledges, and the '30X30 agenda' of a growing coalition of actors lay bare how powerful individuals, organizations, and countries of the Global North can wield influence on the affairs of less powerful countries of the Global South. It is in the persistence of these asymmetries that the urgency of unpacking colonial histories to decolonize the present becomes fully and painfully apparent. The continued deployment of some contemporary and neoliberal conservation approaches in attempts to confront the urgent environmental problems evident today risks exacerbating these on-the-ground inequalities and inviting conservation failures, in part because they amplify these colonial legacies.

\section{Conclusion}

In this article, first, we showed how colonial histories refract and resonate throughout contemporary and market-based conservation initiatives, being especially evident in conservation carried out in formerly colonized places. Through vignettes of political ecology accounts and the patterns these vignettes convey, we demonstrated how some conservation initiatives extend the temporalities and geographies of colonialism, undergird long-standing hegemonies and perpetuate exploitative power structures. These colonial dynamics and their persistence as forms of 'colonial residue' (Collins, 2019) in contemporary and neoliberal conservation initiatives continue to undermine aspirations for truly just and sustainable conservation.

Second, we briefly highlighted how political ecology, as a broad and diverse community of theory and practice, could extend its postcolonial critique through a more explicit engagement with decolonial perspectives. Decolonial gestures within conservation are not new. Conservation practitioners have increasingly sought to integrate communities who are reliant on the environments they seek to conserve into their mandate for conserving nature through various iterations of conservation such as integrated community development projects (see, for example, Büscher et al., 2014). In this respect, these attempts to accommodate local people's concerns and experiences within environments being conserved can be seen as a move towards decolonized conservation, but one that remains severely restricted because of colonially rooted Eurocentrism that shape these interactions. Hence, we argue that any movement towards decolonized conservation requires that conservation be understood as operating in continuous dialogue with the historical and social contexts in which it operates - it must feature an ethos of locally adapted conviviality (Büscher and Fletcher, 2020; Krauss, 2021; Mabele et al., accepted) between humans and the environment. Further, it requires that conservation be pursued as an outcome of social organization rather than as neatly packaged, exogenously set interventions into particular societies. Thus, facilitating decolonized, mutually beneficial partnerships would require the coproduction of priorities and the generation of knowledge that nurtures positive reciprocity between nature and locals' expert lived experiences (Trisos et al., 2021).

Some examples of conservation as outcome rather than exogenous intervention can be found in Southern approaches such as buen vivir, eco-swaraj, and Ubuntu. Buen vivir, for example, is an ensemble of South American perspectives, that encapsulate an openness to other forms of understanding relations between humans and non-humans far beyond any Western human-nature separation (Chuji, Rengifo and Gudynas, 2020) or any purely materialist connections (Albó, 2011). This logic not only questions Western-mandated development due to its obsession with focus on growth and commodification (Chuji, Rengifo and Gudynas, 2020). It also makes 
a key contribution to expanding the ecology of knowledges (Santos, 2007) in an attempt to overcome the tendency of Eurocentric, 'abyssal thinking' of monopolizing judgement on what counts as true 'knowledge.' Instead, buen vivir recognizes the importance of diverse ontologies and epistemologies in valuing how and why nature matters. Buen vivir challenges the primacy of the Eurocentric universal with the pluriversal. The concept thus resonates in all above-described settings in which non-Western knowledges and voices were silenced, devalued or vilified (West, 2016), be they indigenous peoples in Peru, cocoa farmers in Colombia or charcoal producers in Tanzania's miombo woodlands. All our vignettes emphasize the need to challenge colonially entrenched notions of how resources can and should be governed. Rather, we call for dispersed, locally appropriate, more just, and genuinely sustainable ways of living with nature in the spirit of buen vivir. Similarly, we feel that the fundamental ethics of care and reciprocity underlying Ubuntu (Chibvongodze, 2016; Chemhuru, 2019), which highlights communal and mutual responsibility for humans and the environment, resonate strongly with the above-discussed charcoal-making project in Tanzania: its benefits accrue locally, and it relies on local decision-making. Equally, buen vivir and Ubuntu would serve well both of our cocoarelated vignettes' communities to help amplify the voices of Ivorian, Ghanaian, and Colombian cocoa growers and unmask their intersecting vulnerabilities often ignored by powerful stakeholders in the Global North. Finally, eco-swaraj, while respecting planetary limits and other species' rights and promoting social justice and equity, aims to empower every person to be a part of decision-making in the spirit of ensuring a right to and responsibility of meaningful participation (Kothari, 2019). Local empowerment and participation were sorely lacking in both the Nigerian forest policy regulations and Peruvian authorities' treatment of indigenous potato farmers. All our vignettes emphasize the need to challenge colonially entrenched notions of how resources can and should be governed. Rather, we call for dispersed, locally appropriate, more just, and genuinely sustainable ways of living with nature in the spirit of buen vivir, Ubuntu and eco-swaraj.

\section{Bibliography}

Acquaah, B. (1999). Cocoa development in West Africa. Ghana University Press.

Adeyoju, S. K. (1974). Forest resources of Nigeria. The Commonwealth Forestry Review, 53(2), 99-119.

Akoto, G. O., Appiah, K. O., \& Turkson, J. K. (2017). Financial literacy of cocoa farmers in Ghana. International Journal of Accounting and Finance, 7(1), 11-30.

Alberts, H. \& Cidell, J. (2016). Belgian chocolate exports: quality and reputation versus increased chocolate consumption, manufacturing, and quality in Europe and North America. In Squicciarini, M. P., \& Swinnen, J. (Eds.). The economics of chocolate. Oxford University Press.

Albó, X. 2011. "Suma qamaña = convivir bien. ¿Cómo medirlo?" [Suma qamaña = living together well. How to measure it?] in I. H. Farah and L. Vasapollo (eds.) Vivir bien: ¿Paradigma no capitalista? [Living well - Non-capitalist paradigm?], La Paz: CIDES-UMSA, pp. 133-144.

Andriamihaja, O. R., Metz, F., Zaehringer, J. G., Fischer, M., \& Messerli, P. (2019). Land competition under telecoupling: Distant actors' environmental versus economic claims on land in North-Eastern Madagascar. Sustainability, 11(3), 851. https://doi.org/10.3390/su11030851

Asiyanbi, A. P. (2016). A political ecology of REDD+: Property rights, militarised protectionism, and carbonised exclusion in Cross River. Geoforum, 77, 146-156.

Asiyanbi, A., \& Lund, J. F. (2020). Policy persistence: REDD+ between stabilization and contestation. Journal of Political Ecology, 27(1), 378-400. https://doi.org/10.2458/v27i1.23493

Assiri, A. A., Konan, A., N'Guessan, K. F., Kébé, B. I., Kassin, K. E., Couloud, J. Y., ... \& Yao-Kouamé, A. (2015). Comparaison de deux techniques de replantation cacaoyère sur antécédents culturaux nonforestiers en Côte d'Ivoire. African Crop Science Journal, 23(4), 365-378. https://doi.org/10.4314/acsj.v23i4.6

Asuming-Brempong, S. (2003, October). Economic and agricultural policy reforms and their effects on the role of agriculture in Ghana. In Policy Module, Ghana. Role of Agriculture Project International Conference, Rome, Italy. 
Bachram, H. (2004). Climate fraud and carbon colonialism: The new trade in greenhouse gases. Capitalism Nature Socialism, 15(4), 5-20.

Banégas, R. (2006). Côte d'Ivoire: patriotism, ethnonationalism and other African modes of self-writing. African Affairs, 105(421), 535-552.

Bhabha, H. K. (1983). The other question.... Screen, 24(6), 18-36. https://doi.org/10.1093/screen/24.6.18

Blaser, M., de Costa, R., McGregor, D., \& Coleman, W. D. (2010). Reconfiguring the web of life: Indigenous peoples, relationality, and globalization. In Blaser, M., de Costa, R., McGregor, D. and Coleman, W.B. (eds.), Indigenous peoples and autonomy: Insights for a global age (pp. 3-26). UBC Press.

Boatcŏ, M. (2013). Coloniality of labor in the global periphery: Latin America and Eastern Europe in the World-System. Review (Fernand Braudel Center), 36(3-4), 287-314.

Boyd, E., Boykoff, M., \& Newell, P. (2012). The "new" carbon economy: What's new? In Newell, P., Boykoff, M. and Boyd, E. (eds.), The new carbon economy: constitution, governance and contestation (pp. 112). Wiley-Blackwell.

Brandler, J. L. (1993). Out of Nigeria: Witness to a giant's toil. I.B. Tauris.

Bryant, R. L. (1994). From laissez-faire to scientific forestry: Forest management in early colonial Burma, 1826-85. Forest \& Conservation History, 38(4), 160-170.

Bryant, R. L. (1997). The political ecology of forestry in Burma. C. Hurst.

Bryant, R. L. (ed.) (2015). The international handbook of political ecology. Edward Elgar.

Büscher, B., Dressler, W., \& Fletcher, R. (eds.). (2014). Nature Inc.: environmental conservation in the neoliberal age. University of Arizona Press.

Büscher, B., \& Fletcher, R. (2020). The conservation revolution: Radical ideas for saving nature beyond the Anthropocene. Verso.

Buseth, J. T. (2017). The green economy in Tanzania: From global discourses to institutionalization. Geoforum, $86,42-52$.

Campt, T., Grosse, P., \& Lemke-Muniz de Faria, Y.-C. (1998). Blacks, Germans and the politics of imperial imagination, 1920-1960. In S. Friedrichsmeyer, S. Lennox, \& S. Zantop (Eds.), The imperialist imagination: German colonialism and its legacy (pp. 203-231). University of Michigan Press.

Carrasco, L. R., Chan, J., McGrath, F. L., \& Nghiem, L. T. P. (2017). Biodiversity conservation in a telecoupled world. Ecology and Society, 22(3). https://doi.org/10.5751/ES-09448-220324

Chappell, D. A. (1989). The nation as frontier: ethnicity and clientelism in Ivorian history. The International Journal of African Historical Studies, 22(4), 671-696.

Chemhuru, M. (ed.) (2019). African environmental ethics: a critical reader. Springer Nature.

Chibvongodze, D. T. (2016). Ubuntu is not only about the human! An analysis of the role of African philosophy and ethics in environment management. Journal of Human Ecology 53(2), 157-166. https://doi.org/10.1080/09709274.2016.11906968

Chidumayo, E. N. (2017). Biotic interactions, climate and disturbance underlie the distribution of two Julbernardia tree species in miombo woodlands of Africa. Journal of Tropical Ecology, 33(1), 1-11.

Chuji, M., Rengifo, G. \& E. Gudynas (2019). Buen vivir. In: Kothari, A., Salleh, A., Escobar, A., Demaria, F., Acosta, A. (eds). Pluriverse - A Post-Development dictionary (pp. 111-114). Tulika Books.

Cidell, J. L. \& Alberts, H. C. (2006). Constructing quality: The multinational histories of chocolate. Geoforum, 37(6), 999-1007.

Coe, S. D. \& Coe, M. D. (1996). The true history of chocolate. Thames \& Hudson.

Duke, E. \& Krelitz, C. (2015) Baking Boot Camp [presentation]. Charlotte: International Society of Travel \& Tourism Educators Annual Conference.

Collard, R.-C., Dempsey, J., \& Sundberg, J. (2015). A manifesto for abundant futures. Annals of the Association of American Geographers, 105(2), 322-330. 
Collins, Y. A. (2019). Colonial residue: REDD+, territorialisation and the racialized subject in Guyana and Suriname. Geoforum, 106, 38-47. https://doi.org/10.1016/j.geoforum.2019.07.019

Corson, C., \& MacDonald, K. I. (2012). Enclosing the global commons: The convention on biological diversity and green grabbing. Journal of Peasant Studies, 39(2), 263-283.

de Sousa Santos, B. (2007) Beyond abyssal thinking: From global lines to ecologies of knowledges. Review (Fernand Braudel Center), 30(1), 45-89.

Domínguez, L., \& Luoma, C. (2020). Decolonising conservation policy: how colonial land and conservation ideologies persist and perpetuate indigenous injustices at the expense of the environment. Land, 9(3), 65. https://doi.org/10.3390/land9030065

Egboh, E. O. (1985). Forestry policy in Nigeria, 1897-1960. University of Nigeria Press.

Escobar, A., (1995). Encountering development, Princeton University Press.

Evans, M. C. (2021). Re-conceptualizing the role(s) of science in biodiversity conservation. Environmental Conservation, 1-10. https://doi.org/10.1017/S0376892921000114

Fairhead, J., \& Leach, M. (1998). Reframing deforestation: Global analyses and local realities. Routledge.

Fairhead, J. \& Leach, M. (2000). Shaping socio-ecological and historical knowledge of deforestation in Sierra Leone, Liberia and Togo, In R.A. Cline-Cole and C., Madge (eds.). Contesting forestry in West Africa. Ashgate.

Fairhead, J., Leach, M., \& Scoones, I. (2012). Green grabbing: A new appropriation of nature? Journal of Peasant Studies, 39(2), 237-261.

Fanon, F. (2001[1961]). The wretched of the earth. Penguin Books.

Gadgil, M. \& Guha, R. (1992). This fissured land: an ecological history of India. Oxford University Press.

Grosfoguel, R. (1996). From Cepalismo to Neoliberalism: A world-systems approach to conceptual shifts in Latin America. Review (Fernand Braudel Center) 19(2), 131-154.

Grosfoguel, R. (2008a). Developmentalism, modernity and dependency theory in Latin America. In M. Moraña, E. D. Dussel, \& C. A. Jáuregui (Eds.), Coloniality at large: Latin America and the postcolonial debate. Duke University Press.

Grosfoguel, R. (2008b). World-System Analysis and Postcolonial Studies: A call for a dialogue from the "coloniality of power" approach. In R. Krishnaswamy \& J. C. Hawley (Eds.), The Postcolonial and the global. University of Minnesota Press.

Grosfoguel, R. (2011). Decolonizing post-colonial studies and paradigms of political-economy: transmodernity, decolonial thinking, and global coloniality. Journal of Peripheral Cultural Production of the Luso-Hispanic World, 1(1).

Hall, S. (1992). The West and the Rest: Discourse and power. In T. Das Gupta, C.E. James, C. Andersen, G.E. Galabuzi, \& R. C. A. Maaka (Eds). Race and racialization: essential readings (pp. 85-94). Canadian Scholars.

Hidalgo-Capitán, A. L., \& Cubillo-Guevara, A. P. (2019). Good living goals: A proposal for the construction of a global trans-development. Alternautas 6(2), 71.

Hirons, M. A., McDermott, C. L., and Maguire-Rajpaul, V. A. (2017). Responsible chocolate is about protecting both forests and cocoa farmers' livelihoods. Available online at: https://theconversation.com/responsible-chocolate-is-about-protecting-both-forests-and-cocoafarmers-livelihoods-87551

Hook, D. (2005). The racial stereotype, colonial discourse, fetishism, and racism. Psychoanalytic Review, 92(5), 701-734.

Igoe, J., \& Brockington, D. (2007). Neoliberal conservation: A brief introduction. Conservation and Society, 5(4), $432-449$.

Ingram, V. J., Waarts, Y. R., \& van Rijn, F. C. (2018). Cocoa sustainability initiatives: The impacts of cocoa sustainability initiatives in West Africa. In Achieving sustainable cultivation of cocoa (pp. 515-540). Burleigh Dodds Science Publishing. 
Kashwan P., Duffy R., Massé, F., Asiyanbi, A., \& Marijnen E. (2021) From racialized neocolonial global conservation to an inclusive and regenerative conservation. Environment: Science and Policy for Sustainable Development 63(4), 1-19.

Khatun, K., Maguire-Rajpaul, V. A., Asante, E. A., \& McDermott, C. L. (2020). From agroforestry to agroindustry: smallholder access to benefits from oil palm in Ghana and the implications for sustainability certification. Frontiers in Sustainable Food Systems 4: 29. https://doi.org/10.3389/fsufs.2020.00029

Kim, S., Ojo, G. U., Zaidi, R. Z., \& Bryant, R. L. (2012a). Bringing the other into political ecology: Reflecting on preoccupations in a research field. Singapore Journal of Tropical Geography, 33(1), 34-48.

Kim, S., Ojo, G. U., Zaidi, R. Z., \& Bryant, R. L. (2012b). Other political ecologies: introduction. Singapore Journal of Tropical Geography, 33(1), 29-33.

Kothari, A., Salleh, A., Escobar, A., Demaria, F., \& Acosta, A. (eds.) (2019). Pluriverse - A Post-Development Dictionary. Tulika Books.

Krauss, J. E. (2018). Representing environment and development - tracing links between drivers, representations and power dynamics in cocoa sustainability and beyond. Journal of Political Ecology 25(1), 426-445. https://doi.org/10.2458/v25i1.22043

Krauss, J. E. (2021; this collection). Decolonizing, conviviality and convivial conservation: towards a convivial SDG 15, life on land? Journal of Political Ecology 28(1) https://doi.org/10.2458/jpe.3008

Kroeger, A., Bakhtary, H., Haupt, F., \& Streck, C. (2017a). Eliminating deforestation from the cocoa supply chain. World Bank.

Kroeger, A., Koenig, S., Thomson, A., \& Streck, C. (2017b). Forest-and climate-smart cocoa in Côte d'Ivoire and Ghana: Aligning stakeholders to support smallholders in deforestation-free cocoa. World Bank.

Läderach, P., Martinez-Valle, A., Schroth, G., \& Castro, N. (2013). Predicting the future climatic suitability for cocoa farming of the world's leading producer countries, Ghana and Côte d'Ivoire. Climatic Change, 119(3), 841-854.

Lawton, R.M. (1978). A study of the dynamic ecology of Zambian vegetation. Journal of Ecology 66(1): 175198.

Leach, M., \& Scoones, I. (Eds.) (2015). Carbon conflicts and forest landscapes in Africa. Routledge.

Letizia, A. (2013). Battle for the Enlightenment: Neoliberalism, critical theory and the role of circumvential education in fostering a new phase of the Enlightenment. Journal for Critical Education Policy Studies, 11(3), 164-193.

Li, T. M. (2007). The will to improve: Governmentality, development, and the practice of politics. Duke University Press.

Liu, J., Hull, V., Batistella, M., DeFries, R., Dietz, T., Fu, F., Hertel, T. W., Izaurralde, R. C., Lambin, E. F., Li, S., Martinelli, L. A., McConnell, W. J., Moran, E. F., Naylor, R., Ouyang, Z., Polenske, K. R., Reenberg, A., de Miranda Rocha, G., Simmons, C. S., ... Zhu, C. (2013). Framing sustainability in a telecoupled world. Ecology and Society, 18(2), 26. http://dx.doi.org/10.5751/ES-05873-180226

Lohmann, L. (2008). Carbon trading, climate justice and the production of ignorance: Ten examples. Development, 51(3), 359-365.

Mabele, M.B. (2020). In pursuit of multidimensional justice: lessons from a charcoal 'greening' project in Tanzania. Environment and Planning E: Nature and Space 3(4), 1030-1052.

Mabele, M.B., Krauss, J.E. \& Kiwango, W. (accepted). Going back to the roots: Ubuntu and the support for socio-ecologically just conservation in Southern Africa. Conservation and Society.

Maguire-Rajpaul, V. A., Khatun, K., \& Hirons, M. A. (2020). Agricultural information's impact on the adaptive capacity of Ghana's smallholder cocoa farmers. Frontiers in Sustainable Food Systems, 4, 28. https://doi.org/10.3389/fsufs.2020.00028 
Maguire-Rajpaul, V.A., Sandbrook, C., McDermott, C. \& Hirons, M.A., 2021. Climate-smart cocoa governance risks entrenching old hegemonies in Côte d'Ivoire and Ghana: A multiple environmentality analysis. Geoforum. https://doi.org/10.1016/j.geoforum.2021.09.015

Maldonado-Torres, N. (2007). On the coloniality of being: Contributions to the development of a concept. Cultural Studies, 21(2-3), 240-270. https://doi.org/10.1080/09502380601162548

Marmer, E., Marmer, D., Hitomi, L., \& Sow, P. (2011). Racism and the image of Africa in German schools and textbooks. The International Journal of Diversity in Organizations, Communities, and Nations, 10(5), 1-12.

Merino, R. (2018). Reimagining the nation-state: Indigenous peoples and the making of plurinationalism in Latin America. Leiden Journal of International Law, 31(4), 773-792.

Mignolo, W. D. (2009). Epistemic disobedience, independent thought and decolonial freedom. Theory, Culture \& Society, 26(7-8), 159-181. https://doi.org/10.1177/0263276409349275

Mignolo, W. (2009). Coloniality: The darker side of Western modernity. Museo de Arte Contemporaneo de Barcelona. https://monoskop.org/images/a/a6/Mignolo_Walter_2009_Coloniality_The_Darker_Side_of_Moderni ty.pdf

Mignolo, W. (2011). The darker side of Western modernity: Global futures, decolonial options. Duke University Press.

Mignolo, W. (2018). On pluriversality and multipolar world order. In B. Reiter (Ed.), Constructing the pluriverse: The geopolitics of knowledge. Duke University Press.

Mignolo, W. D., \& Walsh, C. E. (2018). On decoloniality: Concepts, analytics, praxis. Duke University Press.

Morris, B. (1970). the nature and origin of Brachystegia woodland. The Commonwealth Forestry Review, 49(2): 155-168.

Nasser, F., Maguire-Rajpaul, V. A., Dumenu, W. K., \& Wong, G. Y. (2020). Climate-Smart cocoa in Ghana: How ecological modernisation discourse risks side-lining cocoa smallholders. Frontiers in Sustainable Food Systems, 4. https://doi.org/10.3389/fsufs.2020.00073

Nayar, P. K. (2015). The transnational in English literature: Shakespeare to the modern. Routledge.

Neumann, R. P. (1998). Imposing wilderness: Struggles over livelihood and nature preservation in Africa. University of California Press.

Newell, P., \& Taylor, O. (2018). Contested landscapes: The global political economy of climate-smart agriculture. The Journal of Peasant Studies, 45(1), 108-129.

Odijie, M. E. (2018). Sustainability winners and losers in business-biased cocoa sustainability programmes in West Africa. International Journal of Agricultural Sustainability, 16(2), 214-227. https://doi.org/10.1080/14735903.2018.1445408

Perreault, T., Bridge, G., \& McCarthy, J. (Eds.) (2015). The Routledge handbook of political ecology. Routledge.

Quijano, A. (2000). Coloniality of power and Eurocentrism in Latin America. International Sociology, 15(2), 215-232.

Quijano, A. (2007). Coloniality and modernity/rationality. Cultural Studies, 21(2-3), 168-178. https://doi.org/10.1080/09502380601164353

Quijano, A., \& Wallerstein, I. (1992). Americanity as a concept: or, The Americas in the modern world-system. International Social Science Journal, XLIV(4), 549-557.

Radkau, J. (1996). Wood and forestry in German history: In quest of an environmental approach. Environment and History, 2(1), 63-76.

Rocheleau, D. E. (2015). Networked, rooted and territorial: green grabbing and resistance in Chiapas. Journal of Peasant Studies, 42(3-4), 695-723. 
Ruf, F. (2015). Diversification of cocoa farms in Côte D'Ivoire: Complementarity of and competition from rubber rent. In Ruf F. and Schroth, G. (Eds.). Economics and ecology of diversification: The case of tropical tree crops. Springer.

Sanial, E., \& Ruf, F. (2018). Is kola tree the enemy of cocoa? A critical analysis of agroforestry recommendations made to Ivorian cocoa farmers. Human Ecology, 46(2), 159-170.

Schroth, G., Läderach, P., Martinez-Valle, A. I., Bunn, C., \& Jassogne, L. (2016). Vulnerability to climate change of cocoa in West Africa: Patterns, opportunities and limits to adaptation. Science of the Total Environment, 556, 231-241.

Schulz, K. A. (2017). Decolonizing political ecology: ontology, technology and 'critical' enchantment. Journal of Political Ecology 24(1), 125-143. https://doi.org/10.2458/v24i1.20789

Scott, J. C. (1998). Seeing like a state: How certain schemes to improve the human condition have failed. Yale University Press.

Spivak, G. C. (1985). The Rani of Sirmur: An essay in reading the archives. History and Theory, 24(3), 247. https://doi.org/10.2307/2505169

Sultana, F. (2007). Reflexivity, positionality and participatory ethics: Negotiating fieldwork dilemmas in international research. ACME: An International Journal for Critical Geographies, 6(3), 374-385.

Sunseri, T. (2009). Wielding the ax: state forestry and social conflict in Tanzania, 1820-2000. Ohio University Press.

Tlostanova, M. (2019). The postcolonial condition, the decolonial option and the postsocialist intervention. In Albrecht, M. (ed.), Postcolonialism cross-examined: Multidirectional perspectives on imperial and colonial pasts and the newcolonial present (pp. 165-178), Routledge.

Trisos, H., Auerbach, J. \& Katti, M. 2021. Decoloniality and anti-oppressive practices for a more ethical ecology. Nature Ecology \& Evolution (2021): 1-8. https://doi.org/10.1038/s41559-021-01460-w

Tuck, E. \& Yang, K. W. (2012). Decolonization is not a metaphor. Decolonization: Indigeneity, Education and Society 1(1), 1-40.

Von Hellermann, P. (2013). Things fall apart? The political ecology of forest governance in southern Nigeria. Berghahn.

West, P., 2016. Dispossession and the environment: Rhetoric and inequality in Papua New Guinea. Columbia University Press.

Wildangel, R. (2020, July 20). Germany's belated debate on colonialism. European Council on Foreign Relations. ECFR. https://ecfr.eu/article/commentary_germanys_belated_debate_on_colonialism

Zimmerer, K. S., Lambin, E. F., \& Vanek, S. J. (2018). Smallholder telecoupling and potential sustainability. Ecology and Society, 23(1). https://doi.org/10.2307/26799052 